\title{
Carcinogen in Alcohol, a Review
}

\section{Prabhjot Bains \\ Department of Pharmacology,CTIPS, Shahpur, Jalandhar,Punjab, India Email- prabhbains35@gmail.com}

\begin{abstract}
Various scientific, preclinical and clinical studies demonstrated a correlation between alcohol consumption and cancer. Chronic alcohol consumption increases the risk of organs and tissues of the body involve respiratory tract, breast, esophageal, liver, upper aerodigestive tract and colorectal cancer in the human body. Epidemiology data identified that it causes significant risk for humans. International Agency for Research on Cancer classified alcohol beverages as a Group I carcinogen to humans. Different types of genes are also responsible for the carcinogenic activity. The mechanism of chronic alcohol consumption with carcinogenesis is not understood fully but possible events include genotoxic effects of acetaldehyde, generation of reactive oxygen species, anomalous metabolism of folate and retinoid, increased estrogen and genetic polymorphism. The main enzymes involved in their metabolism are alcohol dehydrogenase (ADH) and aldehyde dehydrogenase (ALDH). Cytochrome P450 (CYP2E1) also plays an essential role in the mechanism of alcohol. The level of risk increases with an increase in alcohol consumption. Other than acetaldehyde and ethanol in alcohol, several chemical substances like ethanol, acrylamide, alfatoxin, arsenic, cadmium and many more have been present for carcinogenic activity. Various strategies including has been adopted to reduce the carcinogenic activity with alcohol.

Keywords: Alcohol, carcinogenic activity, genes, aldehyde, types, strategies.
\end{abstract}

\section{Corresponding author: Prabhjot Bains}

\section{INTRODUCTION}

Cancer is a generic term that affects every part of the body. The other terms used are neoplasm and malignant tumors. The abnormal and uncontrolled growth of the cells and spread to the other body parts leads to the formation of cancerous cells in the body. This process is called metastasizing. Metastases are the considerable cause of death with cancer [1]. Chronic alcohol drinking is a major health concern over worldwide which may lead to the destruction of almost every organ of the body. Actually, alcohol consumption is an established hazardous factor for various malignancies. In 1988, International Agency for Research on Cancer (IARC) classified alcohol beverages as Group- I carcinogen to humans [2]. In October 2009, 30 scientists met at the IARC to reconsider the carcinogenicity of tobacco, Areca nut, smoking, salt-preserved fish and alcohol [3, 4]. An original connection has been established between alcohol consumption and cancers of the oral cavity, pharynx, esophagus, liver, colon, rectum, and, in women breast cancer [5]. Alcohol is apparently the major factor responsible for expanded risk of head and neck cancer which is listed in various countries, especially in Central and Eastern Europe [6]. Genetic susceptibility also plays an essential role in alcohol-related cancer and information about carcinogen action mechanism has been increased in recent years. Some are the major non-neoplastic diseases which can be caused by alcohol are: Alcoholic polyneuropathy, Alcoholic cardiomyopathy, Alcoholic 
gastritis, Depression and other mental disorders [7,8], Hypertension [9], Hemorrhagic stroke [10], Liver cirrhosis and fibrosis [11], Acute and chronic pancreatitis [12], Diabetes [ Baliunas et al. 2009]. Daily consumption of alcohol around $50 \mathrm{~g}$ increases the risk for these types of cancers by two to three times higher as compared with the risk in non-drinkers. Furthermore, the effects of drinking and smoking appear to be multiplicative and cause a higher risk of cancer. Globally, approx 389,000 cases of cancer show 3.6\% of cancers due to chronic alcohol consumption (5.2\% in men and $1.7 \%$ in women) [13]. The intensity in association with alcohol differs by the location of the cancer, generally for mouth, pharynx and esophagus (comparative risk in the range of 4-7 for $\geq 50 \mathrm{~g}$ of alcohol per day as compared with non drinkers) and less for liver, colorectal and breast cancer ( comparative risk approximately 1.5 for $\geq 50 \mathrm{~g} /$ day) [14].

\section{EPIDEMIOLOGY}

In the starting of the 20th century, French pathologists hypothesized that alcohol contained in absinthe which likely has carcinogen action for the esophagus. The connection between alcohol consumption and cancer risk has been evaluated in epidemiologic case-control and cohort studies.

According to the Centers for Disease Control and Prevention, estimated 88,000 deaths were connected to exaggerated alcohol use in the United States in between 2006 and 2010 [15]. The consumption of alcohol higher than the recommended upper limits $(>24 \mathrm{~g} /$ day for men, $>12 \mathrm{~g} /$ day for women) leads to carcinogenic action. In this practice, among men and women, $10 \%$ and $3 \%$ respectively of the incidence of total cancer was attributable due to alcohol drinking in European countries. Worldwide, a total of approximately 389,000 cases of cancer represent $3.6 \%$ of all cancers (5.2\% in men and $1.7 \%$ in women) from chronic alcohol consumption [16]. A cautiously designed French study denoted that an alcohol drinking of more than $80 \mathrm{~g}$ per day (approx 0.7 litre bottle of wine) is related with a relative risk (RR) of 18 for the growth of esophageal carcinoma, which interpret into an 18-fold elevated cancer risk with alcohol as compared with non-drinkers, whereas smoking more than 20 cigarettes per day resulted in an elevated RR of only five [17].

In 2012, 3.3 million deaths were reported due to alcohol consumption worldwide [18]. In 2014, nearly 16.3 million adults (ages 18 and older) globally and an estimated 679,000 teenagers (ages 12-17) had an alcohol use disorder in the United States [19]. Epidemiology in breast cancer research relating genes characterize women being more affected to alcoholrelated breast cancer risk. A meta-analysis of 38 epidemiological studies exposed that the risk of breast cancer for one, two, or three or more drinks per day increases by $10 \%, 20 \%$, and $40 \%$, respectively [20]. In the United Kingdom's millions of women in cohort study found that during 7 years of follow-up that women who drank between 70 and $140 \mathrm{~g}$ of alcohol per week had a 5\% increase in total cancer as compared with those drinking less than $20 \mathrm{~g}$ per week, and a $13 \%$ increase in breast cancer. In this study, the alcohol-related risk of aerodigestive cancers was definite to women who smoked [21]. Recent study provides that in US adults age 12 to 20 years, $23 \%$ were current drinkers in the past 30 days, $10 \%$ were episodic drinkers, $2 \%$ were heavy episodic drinkers and $6 \%$ met criteria for alcohol use disorder [22].

\section{GENES RESPONSIBLE FOR ALCOHOL RELATED CANCER}

Reports advised that the hazard of cancer for alcohol drinkers is regulated by genetic factors. Various genetic susceptibility affected carcinogenic action in alcohol. Research has directed on variation in genes for Alcohol metabolism, Folate metabolism, and DNA repair. 
A. Genes for Alcohol metabolism- Alcohol dehydrogenase (ADH) is the enzyme that oxidizes ethanol to acetaldehyde [23]. Afterward oxidation of acetaldehyde to acetate is catalyzed by the enzyme called aldehyde dehydrogenase (ALDH). The genes that encrypted for ADH or ALDH are polymorphic which depends on the activity which they encode. They concluded the rate of ethanol metabolism and the concentration of transition metabolites including the carcinogenic AA [24]. There are various classes of human ADH genes and it's the class-I ADH isozymes that are primarily associated with ethanol oxidation. The genes that encode these enzyme types are ADH1A, ADH1B, and ADH1C (foremost nomenclature are $\mathrm{ADH} 1, \mathrm{ADH} 2$, and $\mathrm{ADH} 3$, respectively). European origin has focused on $A D H 1 C$, and in specifically there is a little proof of a powerful effect of this gene on the risk of head and neck cancer.

B. Genes for Folate metabolism- Methylene tetrahydrofolate reductase (MTHFR) converts to 5, 10 methylene tetrahydrofolate and then to 5-methylenetetrahydrofolate, which is necessary for DNA synthesis and methylation. Research on series variants in MTHFR has directed mainly on the 677CÆ $\mathrm{T}$ (accession number rs1801133) variant, which diminishes enzyme activity [25].

C. DNA-repair genes- Arrangement in variants of genes such as XPC, ERCC2, and ERCC1 of the nucleotide-excision pathway, and XRCCI and $O G G 1$. Studies of head and neck cancer have determined interactions between series variants in DNA-repair genes and alcohol consumption, and also there are differences in risks due to these variants by alcohol consumption status [26].

\section{COMMON MECHANISM OF CARCINOGENICITY IN ALCOHOL}

The mechanisms by which alcohol consumption exerts its carcinogenic effect have not been characterized fully, although following reasonable events include [27-29].

Genotoxic effects of acetaldehyde, induction of cytochrome P450 2E1 (CYP2E1) alteration of different xenobiotics, interactions with retinoids, nutritional deficiencies, changes in the degree of DNA methylation, angiogenesis, immune surveillance, increased estrogen concentration which is essential for breast carcinogenesis. However, most studies reported that the co-administration of ethanol elevated the risk of chemically induced carcinogenesis, especially in the upper aerodigestive tract (UADT) [30-32].

Ethanol is removed via its oxidation to acetaldehyde by $\mathrm{ADH}$ and later acetaldehyde is changed to acetate by aldehyde dehydrogenase (ALDH). Various studies have pointed out that an imbalance between the activities of ADH and ALDH play a critical role in alcoholinduced neoplasm [33]. Essentially higher actions of different isoforms have been stated in esophageal cancer [34], liver cancer [35], and cervical cancer [36].

Acetaldehyde may be the significant cancer-causing agent in the upper and lower gastrointestinal tract, as acetaldehyde concentrations in saliva and in the large intestine are enough to facilitate in it and act as a carcinogen [37-42].

Acetaldehyde concentrations in the liver are generally is an effective acetaldehyde metabolizing system. So in the pathogenesis of Hepatocellular Carcinoma (HCC), cirrhosis and oxidative stress may be the most important factors. Excessive alcohol drinking leads to the initiation of the CYP2E1 pathway and may indirectly contribute to Reactive Oxygen species (ROS) production and acetaldehyde development. Excessive alcohol augments catabolism of retinoic acid by alcohol-induced CYP2E1. The interaction of retinoid with various signaling pathways includes estrogen signaling which may favor proliferation and malignant transformation of pre-cancerous cells. Chronic ethanol consumption is also correlated with the failure of immune surveillance of tumor cells. 


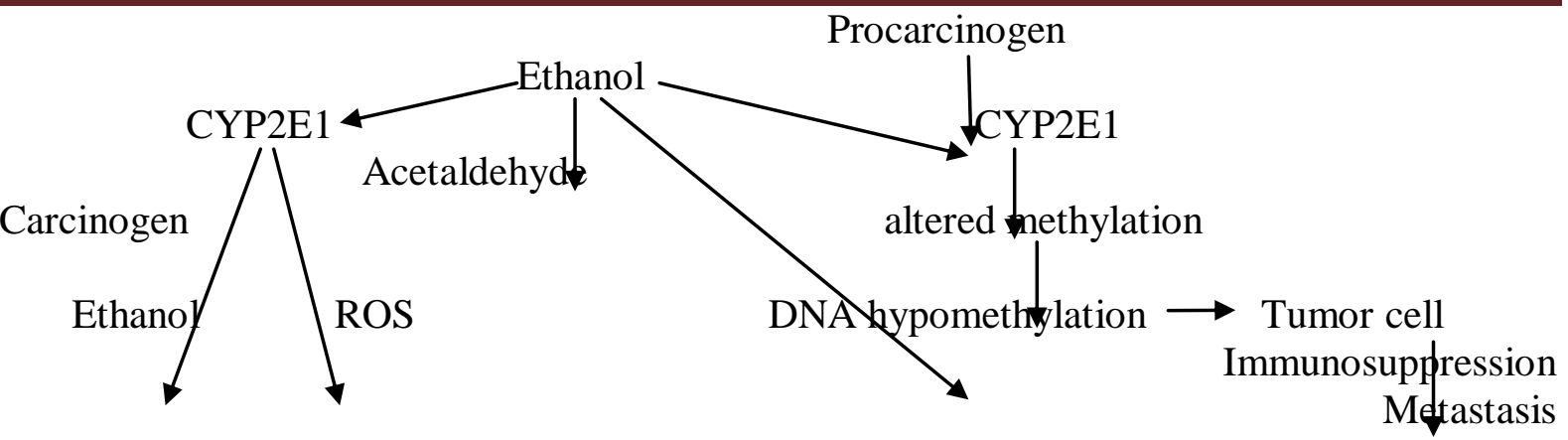

Fig 1: A simplified representation of the mechanisms which shows alcohol influenced carcinogenesis [43]

\section{SUBSTANCES PRESENT IN ALCOHOL BEVERAGES}

WHO International Agency for Research on Cancer (IARC) gives the summary of carcinogenic agents which may be present in alcohol beverages (Updated from IARC) and imagined carcinogenic action [44].

Table 1: List of chemical with the route of exposure

\begin{tabular}{|c|c|c|}
\hline Agent & Toxicological endpoint (Route of exposure) & $\begin{array}{c}\text { IARC } \\
\text { group* }\end{array}$ \\
\hline $\begin{array}{c}\text { Acetaldehyde associated } \\
\text { With alcohol } \\
\text { consumption }\end{array}$ & Significant tumor in animals $\{$ in male rats $\}$ (oral) & 1 \\
\hline Acrylamide & Harderian gland tumor in mice ( oral) & $2 \mathrm{~A}$ \\
\hline Alfatoxins & Liver cancer in human (food) & 1 \\
\hline Arsenic & Lung cancer in human (water) & 1 \\
\hline Benzene & Lymphocyte count in human (inhalation to oral) & 1 \\
\hline Cadmium & Human studies involving chronic exposure (food) & 1 \\
\hline $\begin{array}{l}\text { Ethanol in alcoholic } \\
\text { beverages }\end{array}$ & Hepatocellular adenoma or carcinoma in rats (oral) & 1 \\
\hline $\begin{array}{l}\text { Ethyl carbamate } \\
\text { urethane) }\end{array}$ & (Alveolar and bronchial neoplasm in mice (oral) & $2 \mathrm{~A}$ \\
\hline Formaldehyde & $\begin{array}{l}\text { Histological alteration in the aerodigestive tract which } \\
\text { includes oral and gastrointestinal mucosa of rats (oral) }\end{array}$ & 1 \\
\hline Furan & $\begin{array}{l}\text { Hepatocellular adenomas and carcinoma in female mice } \\
\text { (oral) }\end{array}$ & $2 \mathrm{~B}$ \\
\hline $\begin{array}{l}\text { Lead compound, } \\
\text { inorganic }\end{array}$ & $\begin{array}{l}\text { Cardiovascular effects in humans (dietary exposure } \\
\text { based on blood lead levels) }\end{array}$ & $2 \mathrm{~A}$ \\
\hline 4- methylimidazole & Cancer of lung in mice (oral) & 2B \\
\hline N- nitrosodimethylamine & Total liver tumor (oral) & $2 \mathrm{~A}$ \\
\hline Ochratoxin A & Kidney adenoma and carcinoma in male rats (oral) & 2B \\
\hline Safrole & Hepatic tumor in mice (oral) & 2B \\
\hline
\end{tabular}

IARC group*= Group 1: Carcinogenic to humans; Group 2A: Probably carcinogenic to humans; Group 2B: Possibly carcinogenic to humans 


\section{MECHANISM OF CHEMICALS PRESENT IN ALCOHOL}

Acetaldehyde- Acetaldehyde has been shown to have carcinogenic and mutagenic effects in various in-vitro and in-vivo experiments, including prokaryotic and eukaryotic cell cultures and animal models [45]. It has also been found that to cause point mutations, including in human lymphocytes, DNA adducts (covalent bonds with DNA leads to carcinogenesis) [46], and induce gross chromosomal aberrations and sister chromatids exchanges [47, 48].

Acetaldehyde binds to DNA and forming the stable DNA adducts [49] and this DNA adducts presence has been found in alcohol consumers. The steady-state level of DNA adducts can also be formed by reactive oxygen species (ROS) which can be is influenced by different factors, including the action of the antioxidative defense system, glutathione- $S$-transferase (shows genetic polymorphism), the DNA repair system and apoptosis.

Ethanol- Chronic ethanol drinking induces cytochrome P450 2E1 (CYP2E1), which leads to the formation of ROS and reactive nitrogen species (RNS), which can be neutralized by an effective anti-oxidative defense system (AODS). As the system becomes overloaded by the increased load of ROS and RNS and then DNA damage may occur. ROS-induced lipid peroxidation leads to the formation of lipid peroxidation products like trans-4- hydroxy-2nonenal (4HNE), which can be converted to 2, 3-epoxy-4-hydroxynonenal. An enough DNA repair does not take place because acetaldehyde and nitric oxide (NO) produced by inducible nitric oxide synthase (iNOS), which is induced, by ethanol and inhibits the DNA repair system [50].

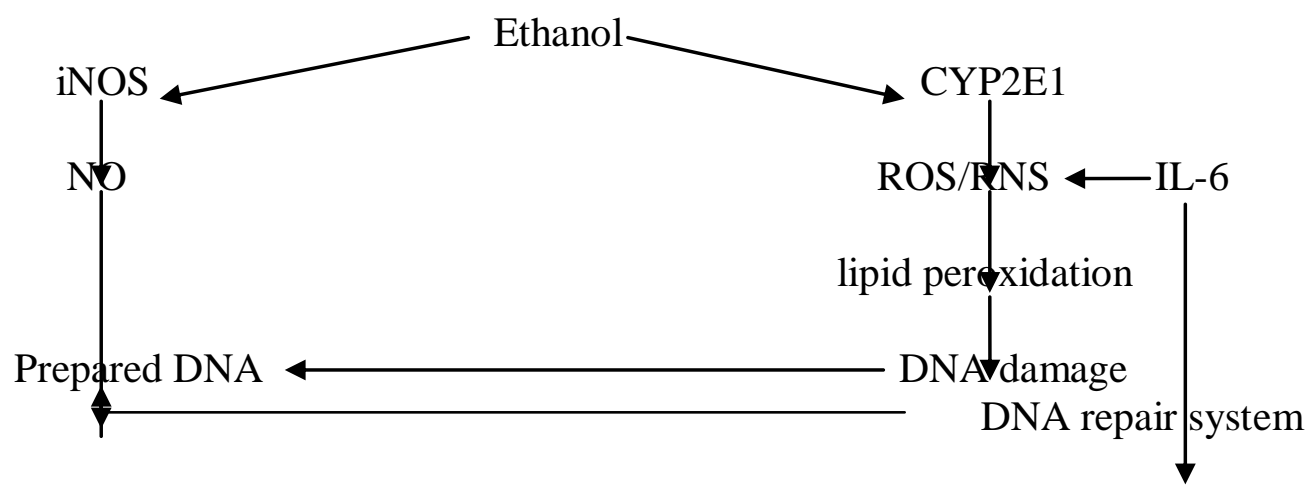

Fig 2: Effect of CYP2E1 and acetaldehyde on DNA damage and repair.

\section{MECHANISM OF OTHER CHEMICALS PRESENT IN ALCOHOL BEVERAGES}

Table 2: Mechanism of chemical with the affected organ

\begin{tabular}{|c|l|c|c|}
\hline Chemical name & Mechanism & Organ affected & References \\
\hline Benzo pyrenene & $\begin{array}{l}\text { Forms adduct with purine bases } \\
\text { of DNA, mainly results in } \\
\text { transversions. }\end{array}$ & $\begin{array}{c}\text { Stomach, Liver, } \\
\text { Skin, Lungs }\end{array}$ & [51] \\
\hline Alfatoxin B1 & $\begin{array}{l}\text { Forms adduct with guanine, } \\
\text { react with RNA and proteins. }\end{array}$ & Liver, Lungs & {$[52]$} \\
\hline Arsenic & Oxidative stress & $\begin{array}{c}\text { Skin, Liver, } \\
\text { Lungs }\end{array}$ & {$[53]$} \\
\hline $\begin{array}{c}\text { N - } \\
\text { Nitrosodimethylamine }\end{array}$ & $\begin{array}{l}\text { Forms adduct at N and O atoms } \\
\text { in DNA bases. }\end{array}$ & $\begin{array}{c}\text { Kidneys, Liver, } \\
\text { Lungs }\end{array}$ & {$[54]$} \\
\hline Cadmium & $\begin{array}{l}\text { Inhibit DNA repair pathways } \\
\text { and nucleotide excision repair. }\end{array}$ & $\begin{array}{c}\text { Lungs, Prostate, } \\
\text { Kidneys }\end{array}$ & {$[55]$} \\
\hline Alkylating agents & $\begin{array}{l}\text { Interstrand or interstrand cross- } \\
\text { links. }\end{array}$ & $\begin{array}{l}\text { Leukaemia } \\
{[51]}\end{array}$ \\
\hline
\end{tabular}




\section{TYPES OF CANCER ASSOCIATED WITH ALCOHOL}

Breast cancer- Chronic alcohol consumption is an identified risk factor for breast cancer and increases breast cancer risk in a dose-dependent manner. Compared to non-drinkers, light drinking (drinking $\leq 1$ drink or $\leq 12.5 \mathrm{~g}$ of ethanol per day) was correlated with a $4 \%$ increased risk of breast cancer, and in heavy drinking (consuming $\geq 3$ drinks per day) with a $40 \%-50 \%$ in elevation of risk [56].

The relation between alcohol consumption and risk of breast cancer has been stated for both premenopausal and postmenopausal women [57]. Increased in estrogen and androgen levels in women consuming alcohol appear to be important mechanisms in their correlation. Other possible mechanisms include increased mammary carcinogen DNA damage, increased mammary gland susceptibility to carcinogenesis, and greater metastatic potential of breast cancer cells. Susceptibility to the breast cancer-strengthen the effect of alcohol which may also be affected by other dietary factors like low folate intake, tumor hormone receptor status or lifestyle habits (use of hormone replacement therapy) [58]. There are also various polymorphisms, involved in estrogen synthesis and metabolism, such as in CYP17, CYP19, CYP1B1, and the catechol- O-methyltransferase, which have been related to breast cancer risk.

Liver cancer- Compared to non-drinkers, consuming $25 \mathrm{~g}$, $50 \mathrm{~g}$ and $100 \mathrm{~g}$ of alcohol per day was related with $20 \%, 41 \%$, and $83 \%$ respectively in increasing the risk in liver cancer [59]. The most possible mechanism of alcohol-related liver carcinogenicity is through the development of liver cirrhosis, although other events like changes in hepatic the metabolism of carcinogens might have a role in liver cancer risk [60].

Esophageal cancer- Regular consumption of $50 \mathrm{~g}$ alcohol per day has been related with a two-fold increased in the risk for esophageal cancer [61]. Chronic alcohol consumption is commonly correlated with secondary motility disorders and lower esophageal sphincter tone alteration. It has also been reported a strong interaction between the effects of alcohol consumption and smoking on esophageal squamous cell carcinoma in individuals with $\mathrm{ADH} 1 \mathrm{~B}$ or ALDH2 risk alleles [62].

Pancreatic cancer- Pancreatic cancer was related to current smoking. Alcohol drinking was associated with increased pancreatic cancer risk, but Talamini et al. [63] have stated that it would significant only among heavy drinkers. The biologic mechanism underlying a connection between alcohol consumption and pancreatic cancer is not fully understood. However, a possible mechanism is through the development of chronic pancreatitis as a result of consumption of alcohol (>80 g/day for 10-12 years) [64].

Colorectal cancer - Studies gives evidence for an increased RR of approximately 10-20\% for colorectal cancer with regular consumption of approximately $50 \mathrm{~g}$ of alcohol/ day, compared with non-drinkers. This relation is similar to both colon cancer and rectal cancer [63]. Dietary factors such as low folate intake are also thought to increase the risk of colorectal cancer by 2-5 times and alcohol adversely affects folate metabolism. Alcohol drinking and low folate intake might be interacting synergistically, or alcohol could act through the folate metabolism to increase the risk of colorectal cancer [60].

Renal cell carcinoma (RCC) - It is the most extensive neoplastic renal disease, accounting for $90 \%-95 \%$ of all reported of renal cancers $[3,4]$. Clear cell renal carcinoma (ccRCC) originated from the epithelium of the proximal tubule and being the most common form of 
RCC. ccRCC is named for the fine appearance of the cytosol when it stained using common histological staining techniques due to the increased lipid accumulation [65].

\section{STRATEGIES TO REDUCE CANCER WITH ALCOHOL}

\section{A. Community strategies [66]}

- Increase alcohol taxes

- Regulate alcohol outlet density

- Commercial Host "Dram Shop" Liability Laws

- Maintain or limit days or hours of sale

- Enhanced enforcement of laws prohibiting sales to minor

B. Clinical strategies

- Alcohol Screening and Brief Intervention Provided in Clinical Settings [67]

- Alcohol Screening and Brief Intervention Provided Using Electronic Devices (e-SBI) [66]

C. Prospective strategy for tumor immunotherapy in alcoholics

One such approach is to recover anti-tumor immunity by targeting iNKT cells and CD8+ T cells. Previously, the B16BL6 melanoma model established an association between alcohol intake and increased iNKT cell number [68].

D. Future preventive strategy [69]

Following points should be practices for prevention of alcohol-related cancer

- Alcohol-related GIT cancer risk is dose-dependent.

- Approximately $80 \%$ of upper gastrointestinal (GI) tract tumors can be prevented by abstaining from alcohol and smoking.

- Alcohol and smoking have synergistic effects.

- Gene mutation-aldehyde dehydrogenase deficiency-increases the risk of alcoholrelated GI tract cancers from 3.4- to 54.2-fold.

- The following care should be taken:

- Avoid heavy drinking

- Avoid smoking

- Take care of practice good oral hygiene

- Avoid drinking to intoxication

\section{CONCLUSION}

Chronic alcohol consumption is one of the most important known causes of carcinogenesis in humans with relating other non-neoplastic risk factors. International Agency for Research on Cancer (IARC) classified alcohol beverages as Group I carcinogen to human. Different types of genes play an essential role in cancer activity with alcohol. Alcohol consumption is increasing rapidly in the worldwide and major hazardous effect on health. Presence of chemical substances in alcohol causes different types of cancer in the human. With heavy smoking and alcohol consumption, the major risk for upper aerodigestive tract including larynx, pharynx, and esophagus. Numerous types of cancer have been originated from alcohol consumption. Various data stated that acetaldehyde is majorly responsible for alcohol-related carcinogen activity. It binds with DNA and proteins and forms DNA adduct which is responsible for its activity. Generation of free radicals also leads to potentiate action in the carcinogenic action. Increased in estrogen level plays a critical role in breast cancer in women. Various strategies have been adopted to reduce the cancer risk with alcohol. Immunotherapy is also a prospective strategy for this.

\section{REFERENCES}

[1] World Health Organization, Geneva, 2017. 
[2] Rehm J, Baliunas D, Borges GLG, et al. - The relation between different dimensions of alcohol consumption and burden disease: an overview. Addiction 2010; 105:817-843.

[3] Secretan B, Straif K, Baan R, et al. Special Report Policy. A review of human carcinogens- Part E: tobacco, area nut, alcohol, coal smoke, and salted fish. Lancet Oncology 2009; 10:1033-34.

[4] International Agency for Research on Cancer (IARC). Alcohol consumption and ethyl carbamate. IARC Monographs. Lyon, France. 2010; 96.

[5] Boyle P, Autier P, Bartelink H, et al. European code against cancer and scientific justification: third version (2003). Ann Oncol 2003; 14: 973-1005.

[6] Bray I, Brennan P, Boffetta P. Projections of alcohol- and tobaccorelated cancer mortality in Central Europe. Int J Cancer 2000; 87: 122-28.

[7] Merikangas KR, Mehta RL, Molnar BE, et al. Comorbidity of substance use disorders with mood and anxiety disorders: results of the International Consortium in Psychiatric Epidemiology. Addict Behav 1998; 23: 893-907.

[8] Rehm J, Room R, Monteiro M, et al. Alcohol use. In: Ezzati M, Murray C, Lopez AD, Rodgers A (eds). Comparative quantification of health risks: global and regional burden of disease attributable to selected major risk factors. Geneva: World Health Organization, 2004: 9591108.

[9] Keil U, Liese A, Filipiak B, et al. Alcohol, blood pressure and hypertension. Novartis Found Symp 1998; 216: 125-44.

[10] Reynolds K, Lewis B, Nolen JDL, et al. Alcohol consumption and risk of stroke: a metaanalysis. JAMA 2003; 289: 579-88.

[11] Corrao G, Bagnardi V, Zambon A, Torchio P. Meta-analysis of alcohol intake in relation to risk of liver cirrhosis. Alcohol Alcoholism 1998; 33: 381-92.

[12] Thakker KD. An overview of health risks and benefits of alcohol consumption. Alcoholism Clin Exper Res 1998; 22: S285-98.

[13] Rehm, J. et al. in Comparative Quantification of Health Risks: Global and Regional Burden of Disease Attributable to Selected Major Risk Factors (eds Ezzati, M., Murray, C., Lopez, A. D., Rodgers, A.) 959-1108 (World Health Organization, Geneva, 2004).

[14] Scoccianti C., Straif K., Romieu I. Recent evidence on alcohol and cancer epidemiology. Future Oncol 2013; 9: 1315-22.

[15] Centers for Disease Control and Prevention: Alcohol use and health. http://www.cdc.gov/alcohol/ fact-sheets/alcohol-use.htm.

[16] Rehm J et al (2004) Comparative quantification of health risks: global and regional burden of disease attributable to selected major risk factors. In: Ezzati M, Murray C, Lopez AD, Rodgers A (eds) World Health Organization, Geneva, pp 959-1108.

[17] Tuyns, A. Alcohol and cancer. Alcohol: Health and Research World 2, 20-31 (1978).

[18] World Health Organization. Global Status Report on Alcohol and Health, 2014; World Health Organization: Luxembourg, 2014; ISBN 978-924-156-475-5. Available online:http://www.who.int/substance_abuse/publications/global_alcohol_report/msb_gsr_ 2014_1.pdf?ua=1 (accessed on 22 June 2017).

[19] Center for Behavioral Health Statistics and Quality. 2014 National Survey on Drug Use and Health: Detailed Tables; Substance Abuse and Mental Health Services Administration: Rockville, MD, USA, 2015. Available online: https://www.samhsa.gov/data/sites/default/files/NSDUH-DetTabs2014/NSDUHDetTabs2014. pdf (accessed on 22 June 2017).

[20] Longnecker, M.P. Alcoholic beverage consumption in relation to risk of breast cancer: Meta-analysis and review. Cancer Causes Control 1994, 5, 73-82.

[21] Allen N. E., Beral V., Casabonne D., Kan S. W., Reeves G. K., Brown A. et al.Moderate alcohol intake and cancer incidence in women. J Natl Cancer Inst 2009; 101: 296-305. 
[22] Richter L, Pugh BS, Peters EA, et al: Underage drinking: Prevalence and correlates of risky drinking measures among youth aged 12-20. Am J Drug Alcohol Abuse 42:385394, 2016.

[23] Brennan P, Lewis S, Hashibe M, et al. Pooled analysis of alcohol dehydrogenase genotypes and head and neck cancer: a huGE review. Am J Epidemiol 2004; 159: 1-16.

[24] Seitz HK, Stickel F. Acetaldehyde as an underestimated risk factor for cancer development: role of genetics in ethanol metabolism. Genes \& nutrition. 2010; 5(2):1218. [PubMed: 19847467]

[25] Sharp L, Little J. Polymorphisms in genes involved in folate metabolism and colorectal neoplasia: a HuGE review. Am J Epidemiol 2004; 159: 423-43.

[26] Hung RJ, Van der Hel O, Tavtigian SV, et al. Perspectives on the molecular epidemiology of aerodigestive tract cancers. Mutat Res published online July 12, 2005. DOI: 10.1016/j.mrfmmm.2005.06.007.

[27] Seitz HK, Stickel F, Homann N Pathogenetic mechanisms of upper aerodigestive tract cancer in the alcoholic. Int J Cancer 2004;108:483-487

[28] Seitz HK, Stickel F - Molecular mechanisms of alcohol-mediated carcinogenesis. Nat Rev Cancer 2007; 7:599-612.

[29] Gyamfi MA, Wan YJY - Pathogenesis of alcoholic liver disease: the role of nuclear receptors. Exp Biol Med 2010; 235:547-560.

[30] Tsutsumi, M., George, J., Ishizawa, K., Fukumura, A. \& Takase, S. Effect of chronic dietary ethanol in the promotion of $\mathrm{N}$-nitrosomethylbenzylamine-induced esophageal carcinogenesis in rats. J. Gastroenterol. Hepatol. 21, 805-813 (2006).

[31] Eskelson, C. D., Odeleye, O. E., Watson, R. R., Earnest, D. L. \& Mufti, S. I. Modulation of cancer growth by vitamin E and alcohol. Alcohol Alcohol 28, 117-125 (1993).

[32] Aze, Y., Toyoda, K., Furukawa, F., Mitsumori, K. \& Takahashi, M. Enhancing effect of ethanol on esophageal tumor development in rats by initiation of diethylnitrosamine. Carcinogenesis 14, 37-40 (1993).

[33] Orywal, K.; Szmitkowski, M. Alcohol dehydrogenase and aldehyde dehydrogenase in malignant neoplasms. Clin. Exp. Med. 2017, 17, 131-139.

[34] Jelski, W.; Kozlowski, M.; Laudanski, J.; Niklinski, J.; Szmitkowski, M. Alcohol dehydrogenase isoenzymes and aldehyde dehydrogenase activity in the sera of patients with esophageal cancer. Clin. Exp. Med. 2009, 9, 131-137.

[35] Jelski, W.; Zalewski, B.; Szmitkowski, M. The activity of class i, ii, iii, and iv alcohol dehydrogenase (ADH) isoenzymes and aldehyde dehydrogenase (ALDH) in liver cancer. Dig. Dis. Sci. 2008, 53, 2550-2555.

[36] Orywal, K.; Jelski, W.; Zdrodowski, M.; Szmitkowski, M. The activity of class i, ii, iii and iv alcohol dehydrogenase isoenzymes and aldehyde dehydrogenase in cervical cancer. Clin. Biochem. 2011, 44, 1231-1234.

[37] Seitz, H. K. et al. Possible role of acetaldehyde in ethanol-related rectal cocarcinogenesis in the rat. Gastroenterology 98, 406-413 (1990). The first study in animals to identify acetaldehyde as a carcinogen and to demonstrate the role of gastrointestinal bacteria in acetaldehyde generation.

[38] Homann, N., Jousimies-Somer, H., Jokelainen, K., Heine, R. \& Salaspuro, M. High acetaldehyde levels in saliva after ethanol consumption: methodological aspects and pathogenetic implications. Carcinogenesis 18, 1739-1743 (1997).

[39] Sarkola, T., Iles, M. R., Kohlenberg-Mueller, K. \& Eriksson, C. J. Ethanol, acetaldehyde, acetate, and lactate levels after alcohol intake in white men and women: effect of 4methylpyrazole. Alcohol Clin. Exp. Res. 26, 239-245 (2002).

[40] Väkeväinen, S., Tillonen. J., Agarwall, D. P., Srivastava, N. \& Salaspuro, M. High salivary acetaldehyde after a moderate dose of alcohol in ALDH2-deficient subjects: 
strong evidence for the local carcinogenic action of acetaldehyde. Alcohol Clin. Exp. Res. 24, 873-877 (2000).

[41] Jokelainen, K., Matysiak-Budnik, T., Mäkisalo. H., Höckerstedt, K. \& Salaspuro, M. High intracolonic acetaldehyde values produced by a bacteriocolonic pathway for ethanol oxidation in piglets. Gut 39, 100-104 (1996).

[42] Jokelainen, K., Siitonen, A. \& Jousimies-Somer, H. In vitro alcohol dehydrogenasemediated acetaldehyde production by aerobic bacteria representing the normal colonic flora in man. Alcohol Clin. Exp. Res. 20, 967-972 (1996).

[43] Helmut K. Seitz and Felix Stickel, Molecular mechanism of Alcohol mediated Carcinogenesis, doi: 10.1038/nrc2191.

[44] IARC Working Group on the Evaluation of Carcinogenic Risks to Humans. Alcohol consumption and ethyl carbamate. IARC Monograph Evaluation Carcinogen Risks Hum 2010; 96:1-1428.

[45] Pöschl G., Seitz H. K. Alcohol and cancer. Alcohol Alcohol 2004; 39: 155-65.

[46] Lachenmeier Dirk W, Rehm J, Carcinogenecity of acetaldehyde in alcoholic beverages: Risk assessment outside ethanol metabolism, October 20, 2017, DOI: 10.1111/j.13600443.2009.02516.x · Source: PubMed.

[47] Obe G., Jonas R., Schmidt S. Metabolism of ethanol in vitro produces a compound which induces sister-chromatid exchanges in human peripheral lymphocytes in vitro: acetaldehyde not ethanol is mutagenic. Mutat Res 1986; 174: 47-51.

[48] Dellarco V. L. A mutagenicity assessment of acetaldehyde. Mutat Res 1988; 195: 1-20.

[49] Wang, M. et al. Identification of DNA adducts of acetaldehyde. Chem. Res. Toxicol. 13, 1149-1157 (2000).

[50] Helmet K Seitz, Stickel F, Molecular mechanism of alcohol mediated carcinogenesis, doi:10.1038/nrc2191.

[51] LUCH A. 2005. Nature and nurture - lessons from chemical carcinogenesis. Nat Rev Cancer 5: 113-125.

[52] WILD CP, GARNER RC, MONTESANO R AND TURSI F. 1986. Aflatoxin B1 binding to plasma albumin and liver DNA upon chronic administration to rats. Carcinogenesis 7: 853-858.

[53] SHI H, HUDSON LG AND LIU KJ. 2004. Oxidative stress and apoptosis in metal ioninduced carcinogenesis. Free Radic Biol Med 37: 582-593.

[54] DRABLOS F ET AL. 1998. Studies of initiation and promotion of carcinogenesis by Nnitroso compounds. Cancer Lett 123: 185-191.

[55] HARTWIG A, ASMUSS M, EHLEBEN I, HERZER U, KOSTELAC D, PELZER A, SCHWERDTLE T AND BURKLE A. 2002. Interference by toxic metal ions with DNA repair processes and cell cycle control: molecular mechanisms. Environ Health Perspect 110 (Suppl 5): 797-799.

[56] Seitz HK, Pelucchi C, Bagnardi V, et al. Epidemiologyand pathophysiology of alcohol and breast cancer: Update2012. Alcohol Alcohol 2012; 47:204-12.

[57] Singletary KW, Gapstur SM. Alcohol and breast cancer: review of epidemiologic and experimental evidence and potential mechanisms. JAMA 2001; 286: 2143-51.

[58] Key J, Hodgson S, Omar RZ, et al. - Meta-analysis of studies of alcohol and breast cancer with consederation of the methodological issues. Cancer Causes Control 2006; 17:759-70.

[59] Bagnardi V, Blangiardo M, La Vecchia C, et al. A meta-analysis of alcohol drinking and cancer risk. Br J Cancer2001; 85:1700-5.

[60] Boeffeta P, Hashibe M, Alcool and Cancer, Lancet Oncol 2006; 7: 149-56

[61] Testino, G. The burden of cancer attributable to alcohol consumption. Maedica 2011, 6, 313-320. 
[62] Yokoyama A, Yokoyama T, Omori T, et al. - Helicobacter pylori, chronic atrophic gastritis, inactive aldehyde dehydrogenase-2, macrocytosis and multiple upper aerodigestive tract cancers and risk for gastric cancer in alcoholic Japanese men. $J$ Gastroenterol Hepatol 2007; 22:210-17.

[63] Talamini R, Polesel J, Gallus S, et al. - Tobacco smoking, alcohol consumption and pancreatic cancer risk: a case-control study in Italy. Eur J Cancer 2009; 46:370-6.

[64] Testino, G. Alcoholic diseases in hepato-gastroenterology: A point of view. Hepatogastroenterology 2008, 55, 371-377.

[65] Radford R, Ryan P.M, Slattery C, Mcmorrow T, Mechanism of chemical carcinogenesis in kidneys, Int. J. Mol. Sci. 2013, 14, 19416-19433; doi:10.3390/ijms 141019416.

[66] Guide to community preventive Services. Preventing Excessive Alcohol Consumption website. Accessed June 24, 2015.

[67] US Preventive Services Task Force. Screening and Behavioral Counseling Interventions in Primary Care to Reduce Alcohol Misuse: Recommendation Statement website. AHRQ Publication No. 12-05171-EF-3. Accessed June 24, 2015.

[68] Zhu, B., Bando, Y., Xiao, S., Yang, K., Anderson, A.C., Kuchroo, V.K., Khoury, S.J. $\mathrm{Cd} 11 \mathrm{~b}+\mathrm{ly}-6 \mathrm{c}(\mathrm{hi})$ suppressive monocytes in experimental autoimmune encephalomyelitis. J. Immunol. 2007, 179, 5228-5237.

[69] Salaspuro P. Mikko, Alcohol consumption and cancer of gastrointestinal tract, Vol. 17, No. 4, pp. 679-694, s2003 doi:10.1053/ybega.2003.393. 